\title{
Exploration of Fabric Typology for Interior Furnishings with Reference to Regional Textile Products of Pakistan
}

\author{
Sadia Farooq ${ }^{1}$, Mohammad Arif Kamal ${ }^{2, *}$ \\ ${ }^{1}$ Department of Family and Consumer Sciences, University of Home Economics, Lahore, Pakistan \\ ${ }^{2}$ Architecture Section, Aligarh Muslim University, Aligarh-202002, India
}

Received September 4, 2020; Revised October 19, 2020; Accepted November 11, 2020

\begin{abstract}
Cite This Paper in the following Citation Styles
(a): [1] Sadia Farooq, Mohammad Arif Kamal , "Exploration of Fabric Typology for Interior Furnishings with Reference to Regional Textile Products of Pakistan," Civil Engineering and Architecture, Vol. 9, No. 1, pp. 166-175, 2021. DOI: 10.13189/cea.2021.090114.
\end{abstract}

(b): Sadia Farooq, Mohammad Arif Kamal (2021). Exploration of Fabric Typology for Interior Furnishings with Reference to Regional Textile Products of Pakistan. Civil Engineering and Architecture, 9(1), 166-175. DOI: 10.13189/cea.2021.090114.

Copyright $\bigcirc 2021$ by authors, all rights reserved. Authors agree that this article remains permanently open access under the terms of the Creative Commons Attribution License 4.0 International License

\begin{abstract}
The fabric is one of the core elements of interior design. The fabrics are important in interior design because they are everywhere and needed by everyone, that helps to attain perfection in design. Many decorations include textiles with interesting patterns, and artists create the images on those textiles. Pakistan has a rich culture and crafts which are deeply rooted in interior textiles in the form of use of colors, designs, materials, and of course the minds which combine them to a memorable piece. The purpose of the study is to find out the use of fabric as a textile product in the interior and to find out the best type of design, texture, color, and pattern in textiles interiors as a fabric. The data are depicted through pictures taken form homes and interviews of house ladies also helped to find out choices for interior textiles. The survey of household textiles concluded that a variety of color, design, and texture is available in fabrics, household ladies preferably use cotton, linen, wool, viscose, polyester, leather, and nylon blends. The fabrics are selected according to the regional suitability, cost, durability, comfort, and aesthetic properties. The bedsheet, pillows, cushions, curtains, towels, wall hangings and coverings, dining sheets, and lamps are popular fabric products in home textiles. The other consideration was for end-use, cost, durability, comfort, and aesthetic properties. Pakistan must promote national products because of its unique design, quality, durability, and low price.
\end{abstract}

Keywords Fabric Types, Interior Furnishings, Textile Products, Pakistan

\section{Introduction}

Interior design is the art and science of observing, listening, and completing the task and wishes of people to develop a sustainable place within a building while considering comfort. Even the meaning of decoration and designing differ a lot but to some extent, they both are used along each other to beautify a place not only visually but also from its functionality. Functional or sustainable products are the need of the era in which a human has to run a race every day with his work and other needs. The elements of sustainability refer to economic, functional, and aesthetical. The more economical the product the more is the demand, functionality can be gained by making products comfortable, feasible, and easy to use and aesthetics require an understanding of elements and principles of design and how to blend them [1,2]. An interior designer can be more capable of doing projects with planning, functional design, and the effective use of space plus to cater to technical issues such as window positioning, acoustics, and lighting as compared to an interior decorator who emphasizes on visual appeal. The interior designers not only work with engineers and architects [1] but they also involve shop keepers, carpenters, ironsmith, fabric makers, etc.

A Textile is a flexible material consisting of a network of natural or artificial fibers, yarn, or thread [1] but not only 
ends up here, but it also has a vast application in human life from wearing suits to covering places such as home to office. It is used not only to cover windows or sofas but its design, texture, and color can vary widely to be suitable with the functional aspect of a space. In other words, it is not only to consider textiles for need but the demand of people, and every person has a unique taste for it. The yarn is produced by spinning raw fibers of wool, flax, cotton, hemp, or other materials to produce long strands, textile is formed by weaving, knitting, crocheting, knotting or tatting, felting, or braiding [2]. Textile in simple words is understandable as fabric by a layperson who called fabric or cloth for almost every use in a household and a workplace [3].

The fabric was present in prehistoric times to cover humans from cold with animal skins, worn at least 70,000 years ago and perhaps much earlier. The next advancement was the use of plant fibers to weave into the fabric, the signs of dyed flax fibers in a cave in the Republic of Georgia dated to 34,000 BCE indicate the presence of textile-like materials in prehistoric times [4].

\section{Interior Textile Designing}

Many decorations include textiles with interesting patterns, and artists create the images on those textiles. Some people have become well known for their textile designs. The other craftsmen are also involved in textile designing who provide variations and variety to people for choosing from the textile industry such as who work on "khadis" for weaving local products, the other technical persons do embroidery, printing, dyeing, batik, screen printing, etc.

The textiles used for interior can be named "Interior textiles" which are produced for either the domestic or contract markets. Domestic textiles are those found in the home or private interiors. "Contract textiles are those found in public or commercial interiors. Interior textiles are usually discussed with two key categories, furnishing fabrics, and household textiles. Furnishing fabrics include upholstery fabrics, soft floor coverings, wall coverings, window furnishing for example curtains, drapes, blinds) and accessories such as cushions and throws". Household textiles include all textiles used in domestic interiors apart from furnishing fabrics. For example, bedding, towels, blankets, tablecloths, and napkins [2,3,5]. Textiles like curtains and carpets are also important element of interior design. A textile is a fabric made by interlacing threads of natural fibers (cotton) or synthetic fibers (nylon) through processes such as weaving or knitting. So, interior textile designers are people who create designs on fabrics that are used for home furnishing and building interiors [6]. The living room or bedroom can be designed with the patterns and textures on carpets, curtains, pillows, upholstered furniture, linens, and blankets. Well-designed textile patterns help pull together a room and give it a distinct feel. Some might focus on domestic interiors, while others concentrate on commercial interests in places like airports, office complexes, or retail establishments [7].

The interior textile industry is classified into:

- Decorative textile

- $\quad$ Textile floor coverings

- Wall coverings

- Manufactured products.

\section{Decorative Textile}

We use textiles for many reasons, including clothing and in our homes. They surround us and over time people have developed many ways to decorate textiles. Decorative techniques used in textiles always produced variations in ordinary designs and patterns to make them up to date. Some methods are as simple as taking a paintbrush and painting on a textile. Other methods are more complicated [8]. Home textiles can be classified as an interior environment, that consists of interior spaces and space-filling products such as furniture and furnishings $[9,10]$. Furnishing includes the feel, color texture, character, feel, and comfort to include in interior products and which cannot be included in the architecture. Fabric is the most comfortable material and even less expensive than other mediums. Three factors attract the eye towards the interior which is given below:

- Color

- Design

- $\quad$ Texture

All these are described in detail in the present paper, also the paper consist of various applications of fabrics used in home textile and their value addition properties obtained by various chemical processing.

\section{Literature Review}

Textile interior is bi functional as it deals with the interior designing and textile designing to produce materials and products which can be used in catering the human requirements and decorating an interior space. The fabric is the main element of structural part of any textile. Embroidery on fabric is also a folk art along with a number of materials which are accessible to nonprofessionals. Examples including Hard anger from Norway, Merezhka from Ukraine, Mountmellick embroidery from Ireland, Nakshi kantha from Bangladesh and west Bengal, and Brazilian embroidery. Many techniques had a practical use such as Sachiko from japan, which was used as a way to reinforce clothing [11]. The fabric is material seen in late back history but embroidery is also present in all eras for enhancing the fabric appearance.

If one has to look in the history of Pakistan about the use 
of different fabrics, the most important is the Mughal era when fabric making of the best quality was at its peak. Many towns like Bengal and Gujrat were famous for their fabric of fine quality in Sultanate period. "Cambay in Gujarat was famous for textiles and for gold and silver work. Sonargaon in Bengal was famous for raw silk and fine cotton cloth (called muslin later on). There were many other handicrafts as well, such as leather work, metal work, carpet weaving, etc. The new crafts introduced by the Turks included the manufacture of paper” [12]. The textile is needed at homes in a large extent because of the qualities of fabrics such as fabric can control sun and light, prevent interior color form fading, reduce glare, Protection from night blackness at evening and too-early sun in the morning, weather protector such as in summer avoid heat and in winter work as conductor for heat loss, expand the room size visually by its colors or reduce the space, work as sound acoustic.

The Pakistani industries are following the six basic techniques for manufacturing textiles such as spinning, weaving, processing, printing, garment manufacturing and filament yarn manufacturing. In fact, cotton is the largest segment of textile production but silk, wool and jute are also major in production, synthetic yarn, filament, fiber are also being produced. Pakistan is advancing in production of synthetic fibers like polyester, acrylic, nylon and polyolefin, the filament yarn like acetate rayon yarn, polyester filament yarn, and nylon filament yarn are popular [12].

\section{Fabric as Furnishing Material in Interior Design}

Fabric is the most usable and affordable material, available in a range from expensive to low price, that can enhance the beauty of an interior. There is not any room or space at homes with our use of fabric even furniture and lighting are most prominent features in rooms but indirectly they are also having fabric combinations. It can be considered as core element of interior design. Fabric adds colors and design to interiors, in other words they complete an interior whether formal or informal. The colors can vary according to the place. Fabric color can be selected according to the use and furniture or color scheme but remember to see the use of that product or place $[13,14]$. The possibility of damage the fabric is always there so to ensure the long-term use, a fabric must be selected according to its usage. A home with kids will be having a different approach for fabric selection, especially for upholstery items which cannot be washed. Here are some fabrics that are regularly used in interior design:

\subsection{Rayon}

It is a fabric like silk but it can be easily and commonly used fabric with great texture, it can have wrinkles frequently so used where not very much in touch with human activities such as in curtains.

\subsection{Silk}

It is a fabric with rich smooth texture and considered a luxurious fabric even now it is available in many varieties according to price but previously it was made for rich people. Silk is popular because of its shine, used in upholsteries where is minimum movement because it gets stains easily so cannot be used all over the home.

\subsection{Cotton}

It is commonly used fabric for all purposes and popular in all classes because of its smooth texture and washable quality. It can be used anywhere and it is also inexpensive. Cotton can be mixed with other yarns to produce other types of fabrics.

\subsection{Nylon}

It is a versatile fabric that has many uses, it is synthetic, hard to tear and can be used roughly because of its wear and tear quality. Nylon can also hold color well. However due to its, strong nature, many a times it is used as in blended forms.

\subsection{Polyester}

It is a strong synthetic fabric used for hard coverings such as on windows and doors etc. the quality of wrinkle free gives it popularity to be used extensively at homes. Like other synthetic fabrics, it is also used as a blend and not its pure form.

\subsection{Leather}

It is a unique fabric made form animal skin and as the rare animal skins are more expensive like silk, adds a rich feel to the interior. Leather is mostly used as a formal material, can mostly be seen being used in offices. Leather is used as sofa and chair covers. It needs special care and can be torn and damaged easily by sunlight and water $[15,16]$.

\section{Significance and Objectives of Research}

Textiles are important in interior design because they can help set a tone or bring elements together for a very finished appearance. Textile products used in interior design include carpets and rugs, curtains, cushions, upholstered furniture and even items like towels and bed 
linens. In interior design, the term "textile" refers to any product that's woven or made of fabric. It may sound simple, but these pieces are used in a variety of applications throughout any room.

The following are the objectives of this research:

- To find out the use of fabric as a textile product in the interior

- To find out the best type of design, texture, color, and pattern is used in textiles interiors as a fabric.

\section{Research Methodology}

Textile can be categorized into many branches so at the first step the sample was delimited to the bed linen, table linen, cushions, wall hangings, wall coverings and lamp shades. The study is a survey of household textiles being used in homes to get insight of the actual situation of the available color, design and texture in fabrics according to the fabric types and depicted with pictures. The sample of study is fabric being used in interior from the residences of Lahore. The decorative textile is delimited to the fabric type being used in interiors. The data was collected from different houses about the materials available and being used in household. There were ten houses selected for the fabric used. The interviews were also conducted from the house ladies who were responsible for the shopping for the home textiles. The table with fabric characteristics was formed with the help of available literature.

\section{Data Analysis and Interpretations}

\subsection{Fabric Types and Advantages}

The fabric types and their advantages were collected from the literature to understand each fabric's quality and uses.

Table 1. Types and Advantages of Fabrics used in Interiors [16,17].

\begin{tabular}{|c|c|c|}
\hline Fiber Type & \multicolumn{2}{|c|}{ Advantages } \\
\hline \multirow{2}{*}{ Cotton / Linen } & Comfort & Moisture \& Thermal Character \\
\cline { 2 - 3 } & Aesthetic & $\begin{array}{c}\text { Low Luster \& Surface } \\
\text { Irregularity. }\end{array}$ \\
\hline Wool & Comfort & Warmth. \\
\hline \multirow{2}{*}{$\begin{array}{c}\text { Viscose / } \\
\text { Modal }\end{array}$} & Cost & Lower than Cotton. \\
\cline { 2 - 3 } & Comfort & $\begin{array}{c}\text { High Moisture Absorption / } \\
\text { Retention Capacity. }\end{array}$ \\
\hline \multirow{2}{*}{$\begin{array}{c}\text { Polyester/Acry } \\
\text { lic Polyamide/ } \\
\text { Polypropylene }\end{array}$} & Cost & $\begin{array}{c}\text { Longer Durability, High Strength } \\
\text { \& Tough. }\end{array}$ \\
\cline { 2 - 3 } & Comfort & $\begin{array}{c}\text { Low Moisture Absorption } \\
\text { Capacity, Low Thermo Plasticity }\end{array}$ \\
\hline
\end{tabular}

Table 1 shows the type of fabrics being used in interiors which include cotton, linen, wool, viscose, polyester, etc. The purpose of capsizing the materials is to abruptly view the properties of fabrics being used and available in the market.

\subsection{Interview Conclusion}

According to the conclusion of interviews the textile interior was selected on the criteria of the fiber composition, textures, color, finishes, and designs, the most of the fabric being used were according to the regional suitability, the other consideration was for end-use, cost, durability, comfort, and aesthetic properties. To achieve the above, the following measurable properties of fibers are mentioned here:

- Moisture Absorption / Content properties.

- Optical behaviors like reflection/absorption of light and shape of the fiber.

- Eco-friendliness

- Electrical and thermal characteristics such as fiber ability to dissipate static charge.

\subsection{Most Items Used in Home Textile}

The data was then categorized into the following items which are the most used item in homes textiles.

\subsubsection{Bed Linen: Bed Covers, Bed Throws, Cushion} Covers, Pillow, Pillow Covers, Quilt Cloth.

8.3.2. Table Linen: Covers, Mats, Napkin, Runners.

\subsubsection{Lunch Box Covers, Apron, Gloves, Pot Holder}

8.3.4. Others: Towels, Wall hangings, lamps, Fabric for Bedsheets, Raw Material such as Cotton and Linen.

Table 2. Bedsheets material being used in Interiors [15,16].

\begin{tabular}{|c|c|c|}
\hline Cloth & $\begin{array}{c}\text { Raw } \\
\text { Material }\end{array}$ & Weave \\
\hline Cambric & $\begin{array}{c}\text { Cotton } \\
\text { or Wool } \\
\end{array}$ & Plain \\
\hline Dimity & Cotton & \begin{tabular}{rlcr} 
Plain & with & \multicolumn{2}{c}{ Cross / Lengthwise } \\
and & Cross & Bar & Effect \\
\end{tabular} \\
\hline $\begin{array}{l}\text { Dotted } \\
\text { Swiss }\end{array}$ & Cotton & Plain(Ground With Swivel, Lappet) \\
\hline Gingham & Cotton & Plain ( Stripe, check Plaids ) \\
\hline Corduroy & $\begin{array}{l}\text { Cotton, } \\
\text { Rayon }\end{array}$ & $\begin{array}{cc}\text { Filling } & \begin{array}{c}\text { Pile with } \\
\text { Back. }\end{array}\end{array}$ \\
\hline Crestone & $\begin{array}{l}\text { Cotton, } \\
\text { Linen, }\end{array}$ & Plain or Twill. \\
\hline
\end{tabular}

Table 2 shows the types of cloth, raw material, and weave used in bed sheets for home textile. 


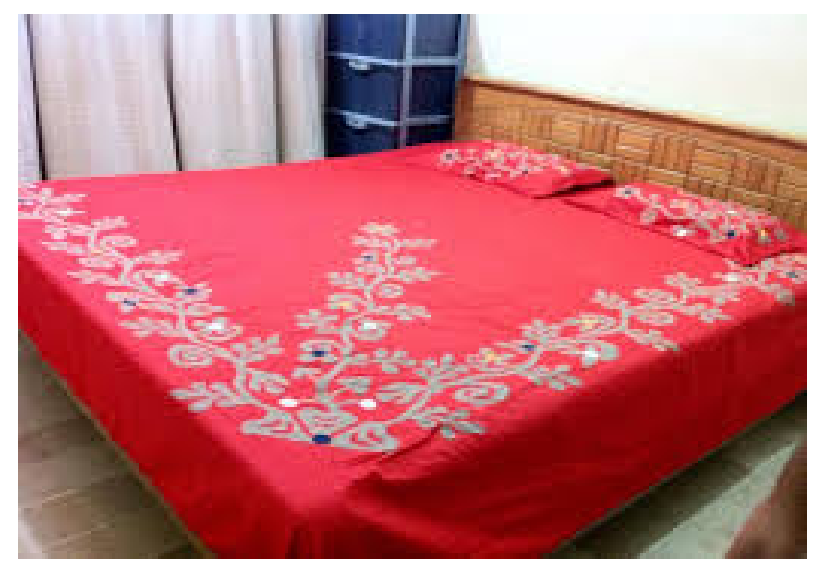

Figure 1. A formal bed sheet

Figure 1 is showing a formal bed sheet made of heavy shiny material which can be cambric, dimity, dotted swiss, Crestone, etc.

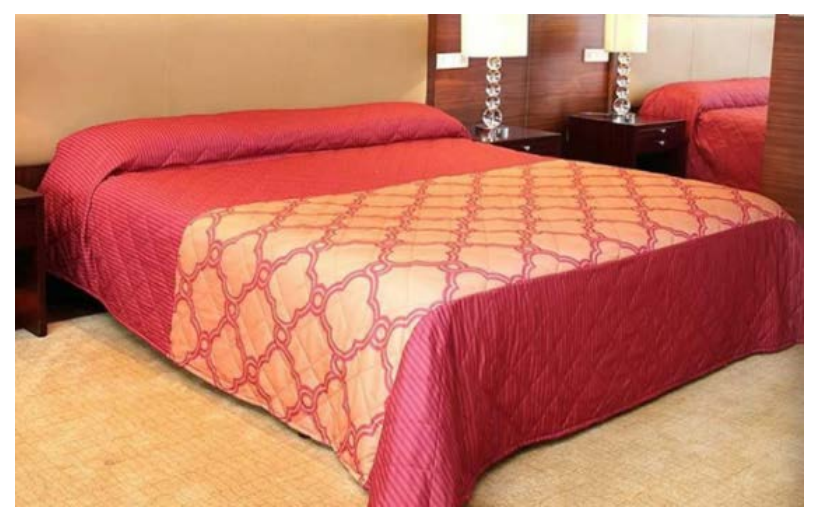

Figure 2. Applique on the linen bed sheet

Figure 2 shows the technique of applique on the bedsheet on linen fabric which is used for comfort and aesthetics.

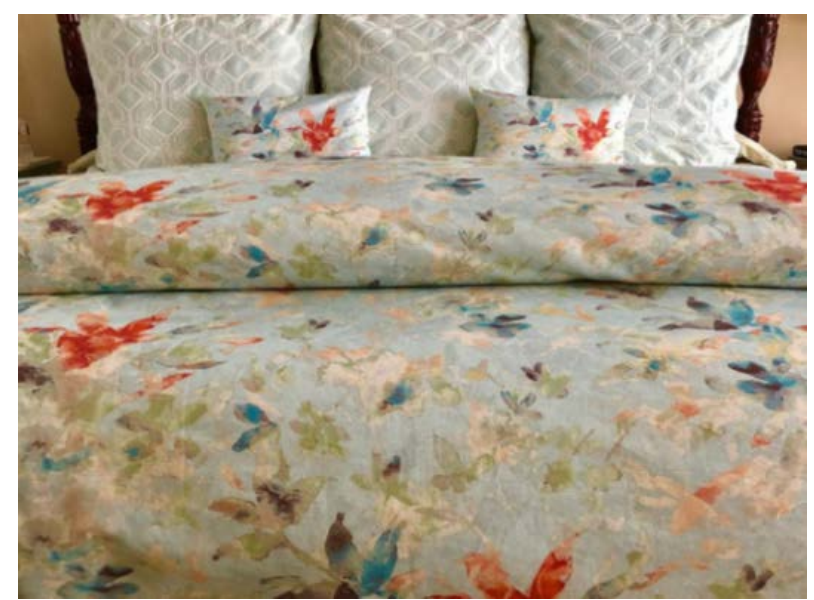

Figure 3. Informal printed cotton bed sheet

Figure 3 shows the informal bed sheet as a bed is used in every house and people use both formal and informal bed sheets according to their comfort.

\subsection{Fabric for Pillow and Cushions}

Raw Materials:

- $\quad$ Feathers of Goose, Rabbit, Down, Duck, etc. (In Cold Countries)

- $\quad$ Polyester, Cotton (In Hot Countries) [15]

Table 3. Pillow and Cushions being used in Interiors [15] [16]

\begin{tabular}{|c|c|c|}
\hline Cloth & Raw Material & Weave \\
\hline Cretonne & Cotton, Linen, & Plain, Twill weaves \\
\hline Ticking & Cotton, Rayon & $\begin{array}{c}\text { Twill (L2, L3) Satin, Dobby } \\
\text { \& Jacquard }\end{array}$ \\
\hline
\end{tabular}

Table 3 shows the cloth, raw material, and weave used in pillows and cushions in home interiors.

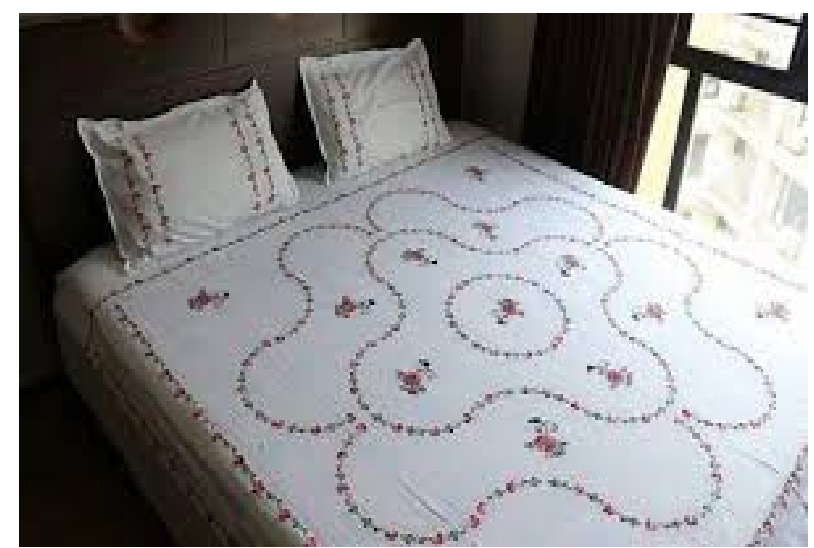

Figure 4. Embodied cotton bedsheet and pillows

Figure 4 shows the embroidery on the whole bed sheet and pillows to enhance the beauty of the fabric which can be simple cotton to dimity.

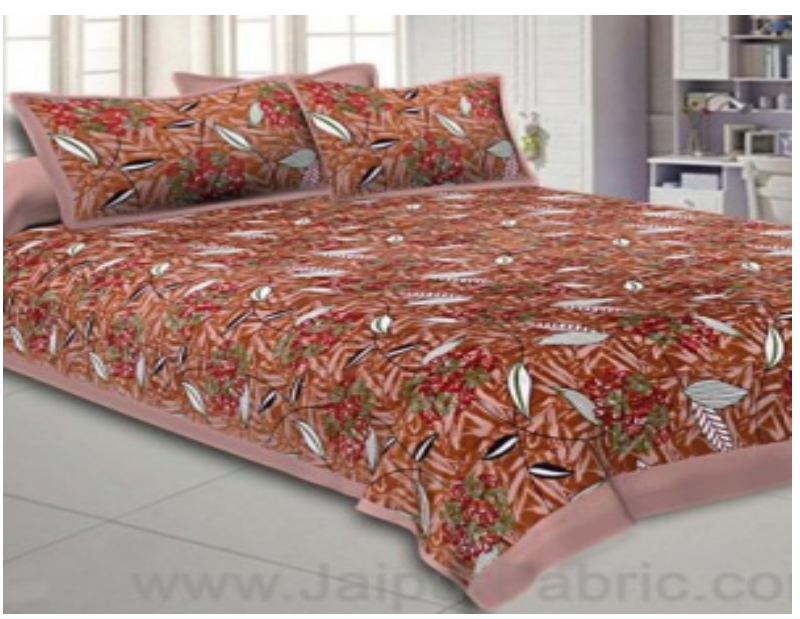

Figure 5. Printed linen bed sheet and pillows

Figure 5 shows the dark colors which are a consumer choice to select design and colors. 


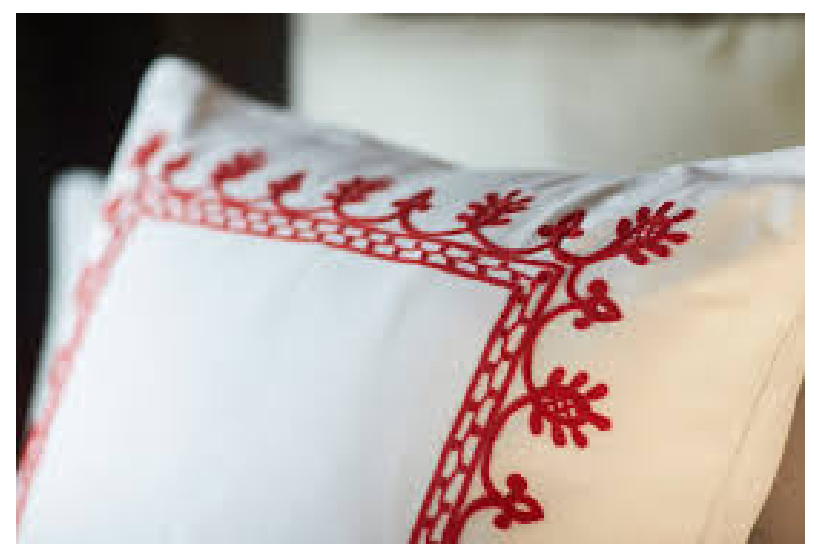

Figure 6. Machine embroider cushion

Figure 6 shows the machine embroidery on cushions which can be custom made according to user choice. The color, design, and materials for fabric and thread can vary.

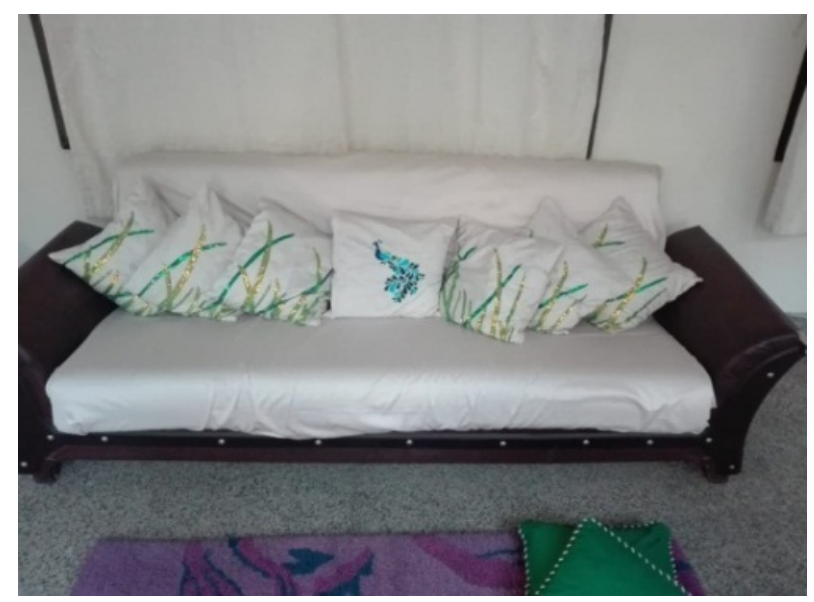

Figure 7. Framework (stars embellishment) on a cushion

Figure 7 shows custom-made cushions, an embellishment of shiny stars in the form of peacock and grass.

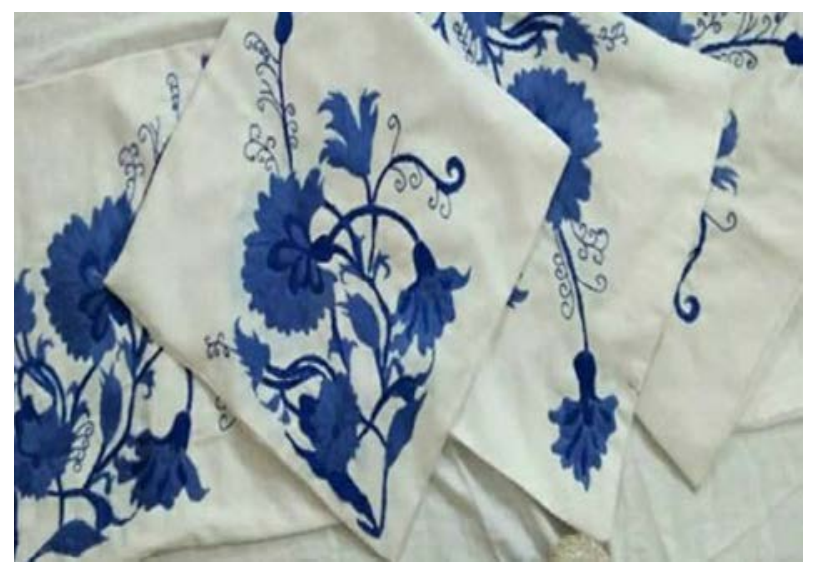

Figure 8. Embroidery work on cushions

Figure 8 shows the heavy embroidery in tones of a monochromatic hue of blue which is hand embroidery and showing the skill and neatness of the embroider.

\subsection{Fabric for Towels}

Raw Material: Cotton, Viscose, Modal. It can be made up of the following cloths:

Table 4. Types of Towels used in Interiors.

\begin{tabular}{|c|c|c|}
\hline Cloth & Raw Material & Weave used [15,16] \\
\hline Gingham & Cotton & Plain (Stripes, Checks, Plaid) \\
\hline Terrycloth & Cotton, Linen & Terry (3pick, 4 pick, 5 pick) \\
\hline
\end{tabular}

Table 4 shows the cloth, raw material, and weave used in towels being used in interiors.
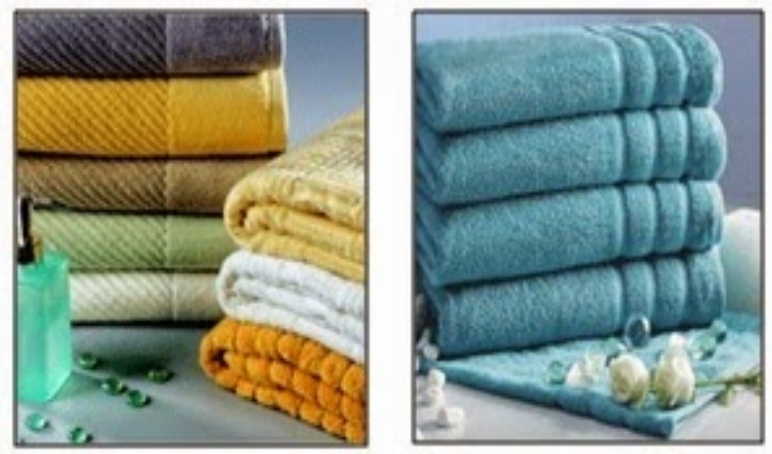

Figure 9. Towels in different colors

\subsection{Fabric for Blankets and Quilts}

Raw material: Woolen, Cotton, P/C, Acrylic $[15,16]$.

Table 5. Types of Blankets and Quilts used in Interiors

\begin{tabular}{|c|c|c|}
\hline Cloth & Raw Material & Weave \\
\hline Calico & Cotton & Plain \\
\hline Chinchilla & Cotton, Wool & $\begin{array}{c}\text { Sateen, Twill with Extra } \\
\text { Filling }\end{array}$ \\
\hline Flannelette & Cotton & Plain; Twill \\
\hline
\end{tabular}

Table 5 shows the cloth, raw material, and weave used in blankets and quilts being used in interiors.

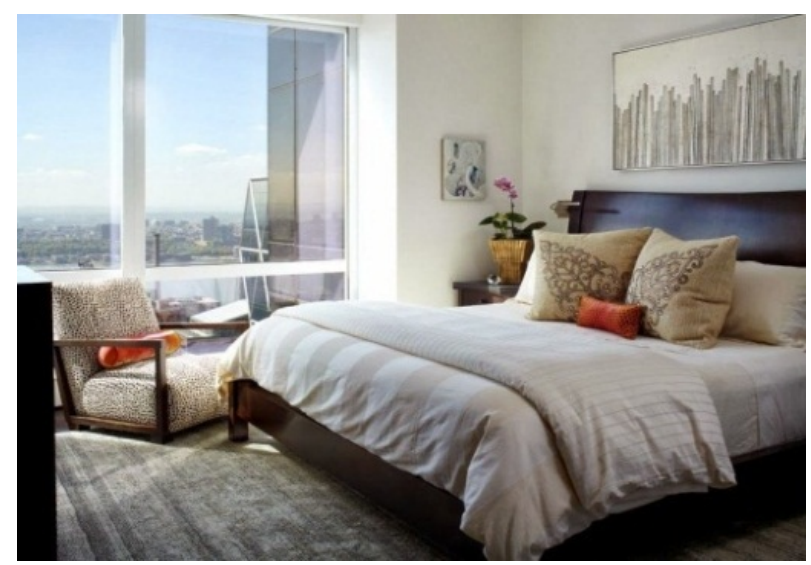

Figure 10. Informal blanket 
Figure 10 shows the quilts matching with the bedsheet and cushions in earthy tones.

\subsection{Fabric for Table Cloth}

Raw Material: Cotton, Polyester.

Table 6. Types of Blankets and Quilts used in Interiors

\begin{tabular}{|c|c|c|}
\hline Cloth & Raw Material & Weave \\
\hline Brocade & $\begin{array}{c}\text { Cotton (Ground), Viscose } \\
\text { (Pattern) }\end{array}$ & Jacquard, Dobby \\
\hline $\begin{array}{c}\text { Monk's } \\
\text { Cloth }\end{array}$ & $\begin{array}{c}\text { Wool, Cotton, Linen, } \\
\text { Silk, Rayon }\end{array}$ & $4 * 4$ Basket Weave \\
\hline Chenille & Cotton & Plain \\
\hline
\end{tabular}

Table 6 shows the cloth, raw material, and weave used in table clothes being used in interiors.

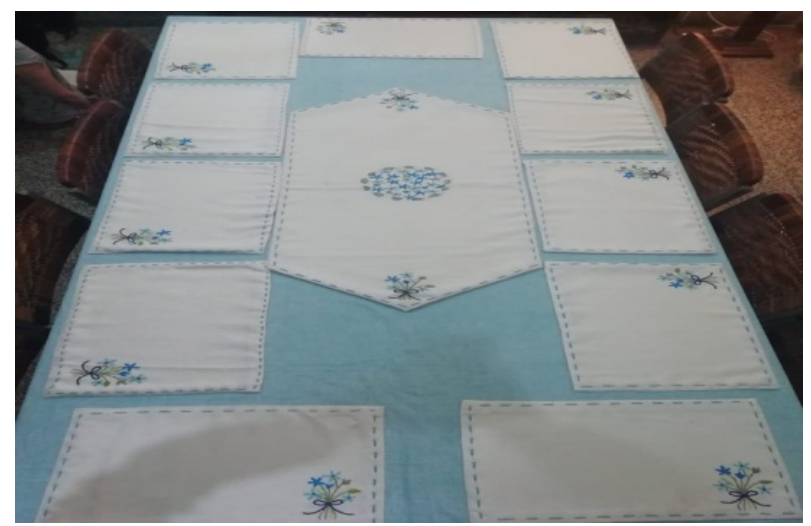

Figure 11. Embroidered table mats

Figure 11 shows the dining cover with contrast table mats with light embroidery.

\subsection{Fabric for Furnishing and other uses}

Raw Materials: Cotton, Polyester \& Silk

Table 7. Types of Blankets and Quilts used in Interiors.

\begin{tabular}{|c|c|c|}
\hline Cloth & Raw Material & Weave \\
\hline Brocade & $\begin{array}{c}\text { Cotton (Ground), } \\
\text { Viscose (Pattern) }\end{array}$ & Jacquard, Dobby \\
\hline Chenille & Cotton & Plain \\
\hline Organza & Cotton & Plain with swivel, lappet \\
\hline Lawn & Cotton & Plain \\
\hline Gingham & Cotton & Plain(Stripes, Checks, Plaids) \\
\hline $\begin{array}{c}\text { Point de } \\
\text { sprit }\end{array}$ & Cotton, Silk & Leno, Gauze \\
\hline Voile & Cotton, wool & Plain loosely woven \\
\hline
\end{tabular}

Table 7 shows the cloth, raw material, and weave used in furnishing fabrics being used in interiors.

The furnishing fabric which is discussed below is windows such as for curtains, wall coverings, wall hangings, cushions

\subsubsection{Curtain Fabrics}

The raw material used: Polyester, flax, viscose, cotton, silk, acetate, jute, hemp \& glass.

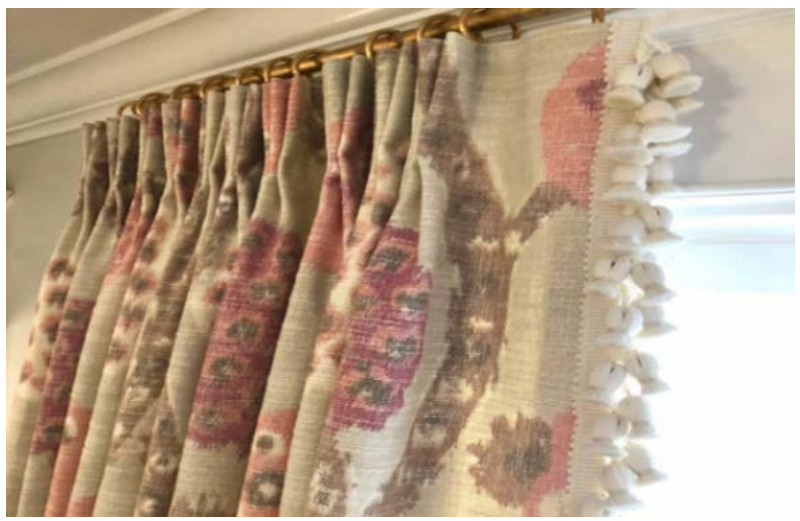

Figure 12. Draperies in printed fabrics for windows

\subsubsection{Wall Covering}

They are taking over the market from paints.

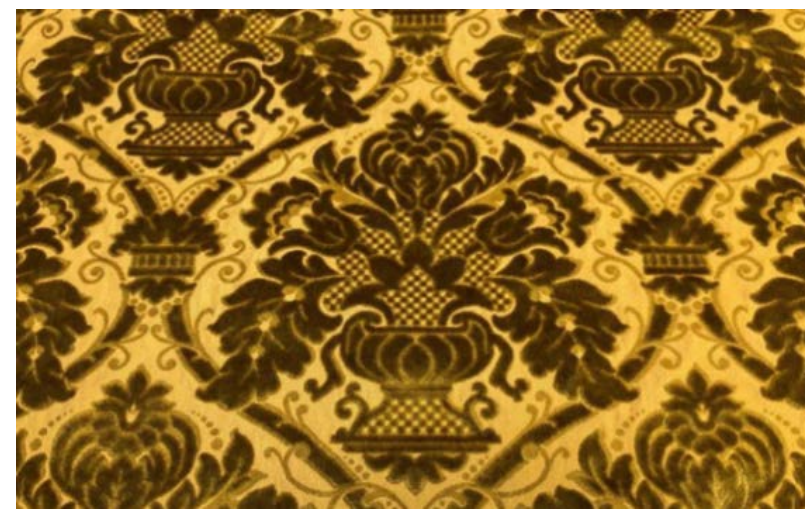

Figure 13. Fabric used as wall paper

Figure 13 shows the printed fabric which can be used on walls, mostly they are used in rooms for sound acoustics and kids' rooms.

\subsubsection{Cushion Covers}

Raw Material: Cotton, Polyester, P / C, other Synthetics 


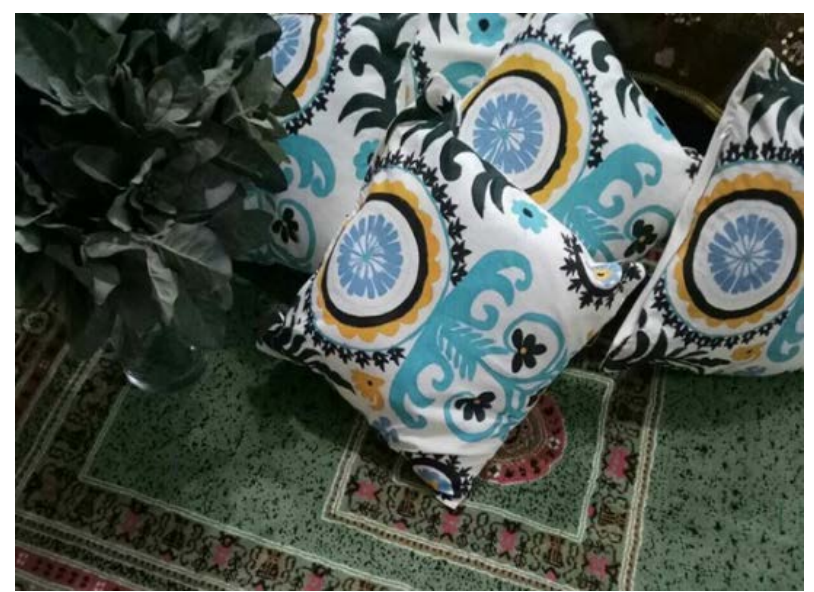

Figure 14. Painted cushion covers

Figure 14 shows the printed cushions which can be used for informal settings such as for lounge.

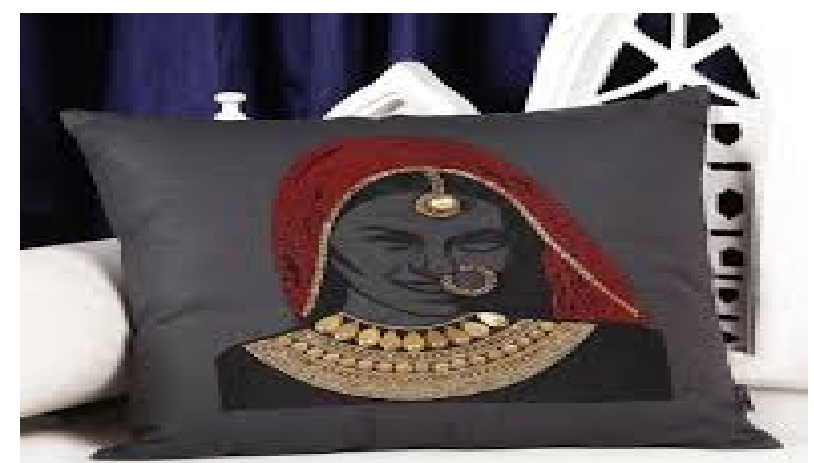

Figure 15. Fashion related cushion covers

Figure 15 shows the cushions with a screen-printed picture of a woman, such type of cushions can be customized and expensive.

\subsubsection{Wall Hangings}

Metal complex dyes are used primarily for subdued shades and acid dyes for brilliant shades. Yarn is moth proofed. The batik style of printing is also in use.

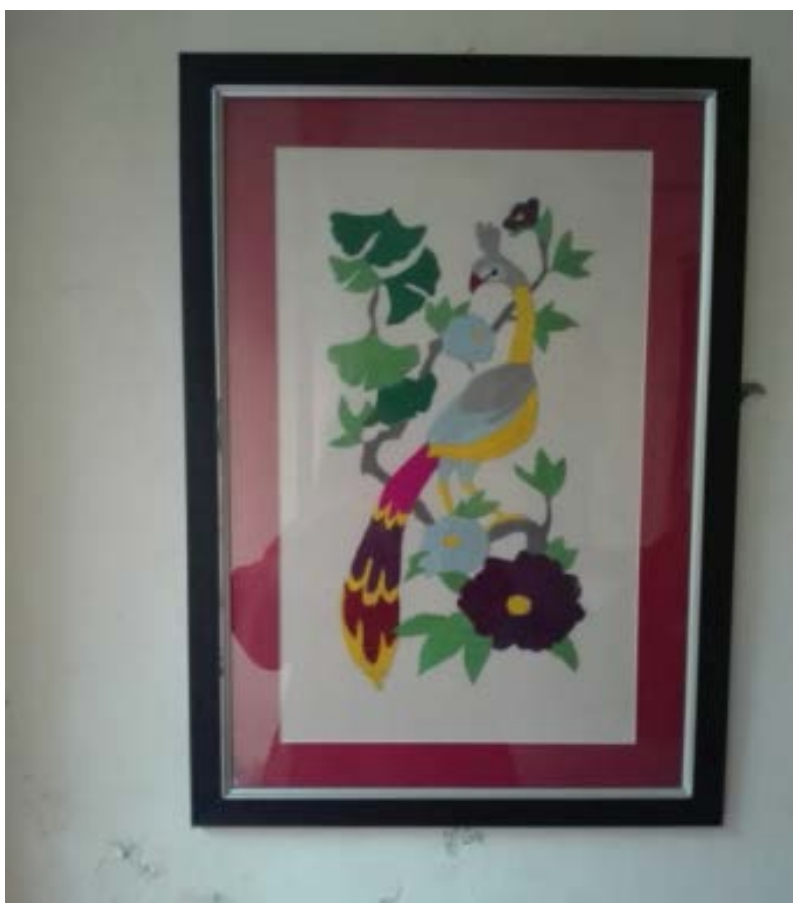

Figure 16. Embroidered fabric wall hanging

Figure 16 shows the wall hanging with embroidery which is showing a complete bird picture with intricate colors.

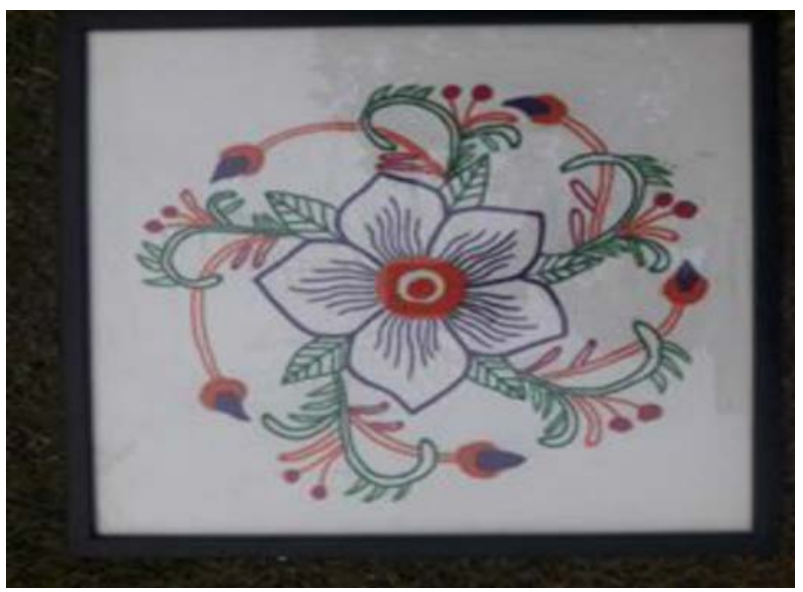

Figure 17. Embroidered wall panels with a floral motifs 


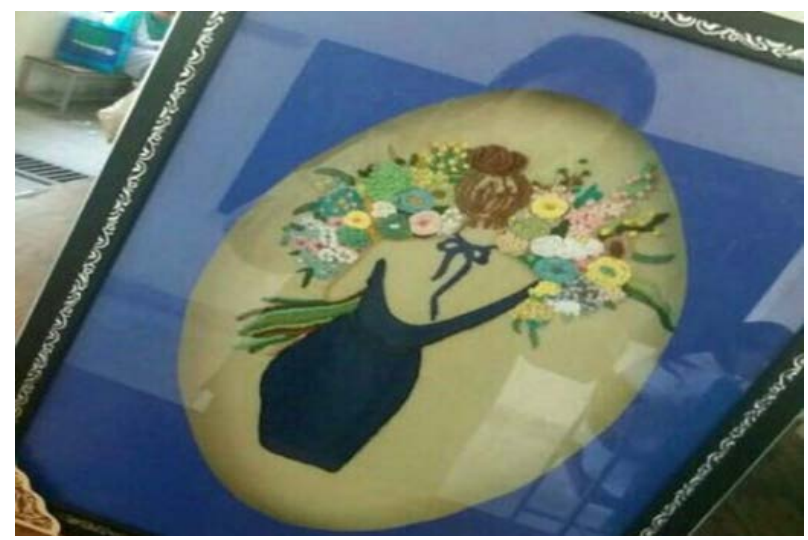

Figure 18. Embroidered wall hanging

Figure 18 shows the wall hanging which is an image of a lady from her backside and flowers in her hands are showing a bouquet.

\subsubsection{Lampshades}

Lampshades are classified into four basic shapes: drum, empire, bell, or coolie depending on their shape. A drum or cylinder shade typically features vertical sides, sometimes with a very slight incline where the top of the shade is slightly smaller than the bottom.

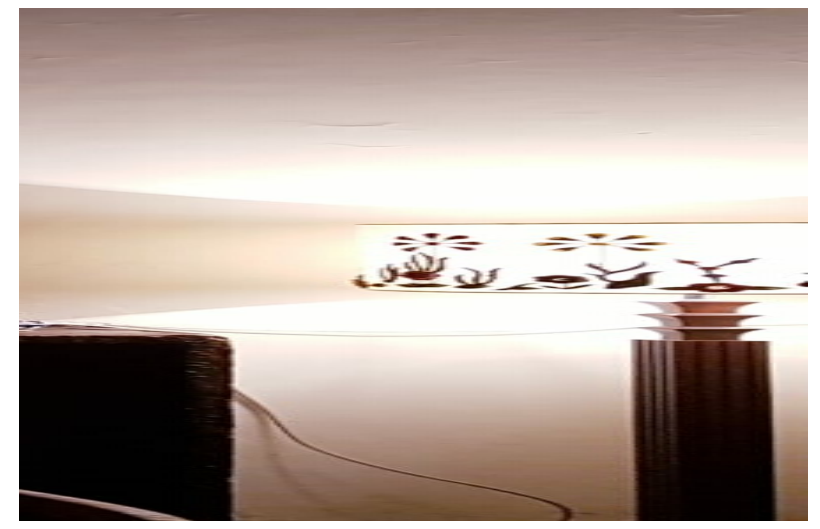

Figure 19. Embroidered Lamp shades for a side table

Figure 19 shows the lampshade with embroidery which is used to up on side tables.

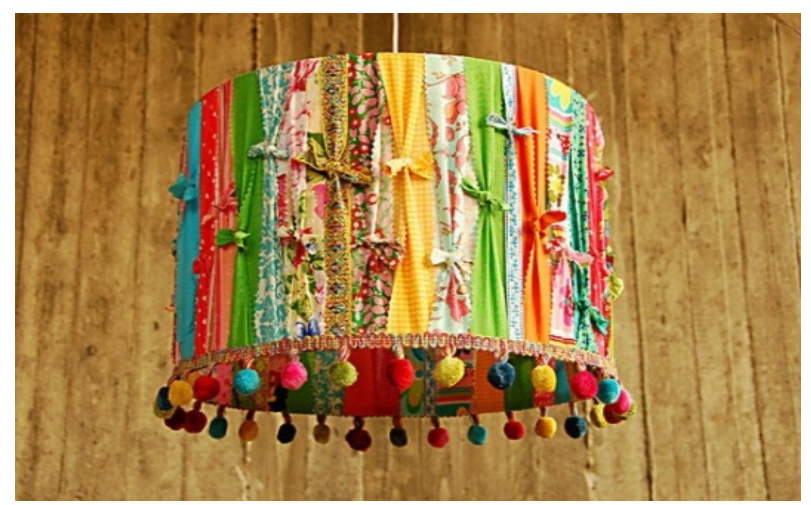

Figure 20. Handmade Lamp shade with colored fabric stripes

\section{Discussion and Conclusion}

The study concluded that the textile interior cannot be ignored as the fabric that is not only for wearing but is being used everywhere in interiors [1,2]. Pakistan is always famous because of its crafts and fabric that has unique combinations of colors, designs, and materials. The survey of household textiles concluded that a variety of color, design, and texture [2,7] is available in fabrics according to its kinds, a few examples are shown in pictures, taken from selected residences of Lahore. A brief interview or discussion with household ladies also gave an insight of the materials being used in household, most of them are using cotton, linen, wool, viscose, polyester, leather and nylon blends $[3,6,12,15,16]$. They select fabric because of textures, color, finishes, and designs, the most of the fabric being used are according to the regional suitability, the other consideration was for end-use, cost, durability, comfort and aesthetic properties [2,13,14]. The types of cloth, raw material, and weave used in bed sheets are having a wide variety to choose from. The formal bed sheet made of heavy shiny material, use of the technique of applique, and embroidery both hand and machine-made are also being used for both formal and informal bed sheets. The pillow and cushions cloth are being selected by filling and weave types $[15,16,17]$. The dark and cool colors both, tones of a monochromatic, earthy tone are in use which is a consumer choice to select design and colors. Different embellishment like stars and figures of animals are common. Towels, blankets, and quilts are being made in different colors and weaves. The dining cover with contrast table mats with light embroidery is popular, draperies in printed fabrics, and wall covering fabric used for sound acoustics. Informal cushions in the lounge with screen printing are famous but customized cushions are expensive [3,5], wall hanging with embroidery in figures and floral designs are also in use. Lampshades are in use in different shapes, materials, and colors. The need is to promote our national products in other regions not only because of the aesthetic qualities but quality, durability, and low price. Even, the Pakistani textiles are greatly demanded in all over the world but new techniques and materials are being embedded in the industry to maintain the exports [12]. The textile products are valuable and in demand because of their uniqueness, the fabric quality, thread, techniques are always welcomed inside and outside country. The need is to highlight the modern techniques and to raise the exports for both hand work and machine work.

\section{REFERENCES}

[1] D. J. Huppatz, The cave: Writing design history. Journal of Writing in Creative Practice, 3(2), 135-148, 2010. 
[2] W. J. Mitchell, A. S. Inouye \& M. S. Blumenthal. Beyond productivity: Information technology, innovation, and creativity. Washington, DC: National Academies Press, 2003.

[3] M. Balter, Clothes make the (Hu) man, Vol. 325, pp. 1329, 2009.

[4] A. S. Salim, Literature in dyes for industrial fields. International Journal of Chem-informatics Research, 5(1), 36-40, 2019.

[5] M. Burman, Analog. Diploma work, 2019.

[6] J. Gillow, B. Sentance, World Textiles. Bulfinch Press/Little, Brown, 1999.

[7] P. Stephanie, Architectural Design and History, Design Elements \& Symbols-Triquetra: Definition \& History, 2018.

[8] K. J. Nielson, Interior Textiles: Fabrics, Application, and Historic Styles, John Wiley \& Sons, 2007.

[9] V. Colton, (Ed.). (1979). Reader's Digest Complete Guide to needlework.

[10] S. Caroline 'The Skill of the Two Hands'. Saudi Aramco World, Saudi Arabia, May-June 2007.

[11] R. Netherton, O. Crocker, Medieval Clothing and Textiles, Volume 1. American Historical Review, 110(5), 1643, 2005
[12] S. R. Lewis, Economic policy and industrial growth in Pakistan (pp. 78-80). London: Allen \& Unwin, 1969.

[13] K. J. Nielson, Interior textiles: fabrics, application, and historic style. John Wiley \& Sons, 2007.

[14] T. Das, Surface design of fabrics for interior textiles. In Interior Textiles (pp. 91-118). Woodhead Publishing, 2009.

[15] J. W. Hearle, (Ed.). High-performance fibers. Elsevier, 2001.

[16] P. K. Hari, Types and properties of fibers and yarns used in weaving. In Woven Textiles (pp. 3-34). Woodhead Publishing, 2020.

[17] Report on Quality Parameters for Home Textiles, Bombay Textile Research Association, 2004.

[18] R. F. Voss, J. Clarke. Algorithmic Musical Composition, Silver Burdett Press, Londyn, 1986.

[19] W. Zabierowski, A. Napieralski. Chords classification in tonal music, Journal of Environment Studies, Vol.10, No.5, 50-53.

[20] A. Abiewskiro,. Z. Moplskiiera. The Problem Of Grammar Choice For Verification, TCSET of the International Conference, House of Lviv Polytechnic National University, 19-23, 2008. 